\title{
EVALUATION OF CORN SILAGE FROM DIFFERENT REGIONS IN EGYPT
}

\author{
Daoud E.N..$^{*}$; Soliman ${ }^{2}$ H.S.; Elsayed ${ }^{2}$ H.M., Elbordeny ${ }^{2}$ N.E. and \\ Gihan M. El-Mogazy
}

1. Regional Center for Food and Feeds, Agric. Res. Center, Giza, Egypt

2. Animal Production Dept., Fac. of Agric., Ain Shams Univ., P.O. Box 68 Hadyek Shoubra, 11241 Cairo, Egypt

*Corresponding author: daoudsantana@yahoo.com

Received 28 August, 2018, Accepted 2 October, 2018

\begin{abstract}
The main objective of this study was to evaluate different samples of corn silage (Whole corn plant with ears) from different regions in Egypt to determine each sample has the highest nutritive value and nutrients digestibility and therefore reduce the feed cost, increase feed efficiency and probability of lactating dairy farms. Silage samples were collected from different four areas in Egypt; El-Salhya, El-Nobarya, El-Monofia and Ganakles. The study Included three field and laboratory work cores which were; chemical composition, in-vitro and in-situ evaluation studies.

The samples were analyzed for its chemical composition, Dry matter (DM), crude protein (CP), neutral detergent fiber (NDF), acid detergent fiber (ADF) and acid detergent lignin (ADL). The silage samples were evaluated in-vitro and in-situ. In-vitro evaluation was conducted using gas production technic. Gas production (GP) was recorded at 0, 2, $4,8,16,24$ and 48 hours of incubation. The organic matter digestibility (OMD), short chain fatty acids (SCFA), and metabolizable energy (ME) were measured. The in-situ experiment, involved nylon bags containing silage samples from different regions were incubated in three fistulated Barki rams for 24h. Samples were taken out at 2, 4, 8, 12 and $24 \mathrm{~h}$ of incubation. The obtained results indicated that the Ganakles silage ampel recorded the lowest $(P<0.01)$ values of GP within the different times compared to others. The silage from El-Salhya had the highest $(P<0.01)$ values for OMD and SCFA. The DMD of in-situ samples was significantly $(P<0.01)$ increased within the different times of incubation with Al-Salhia silage samples, but the lowest significant values $(P<0.01)$ were recorded
\end{abstract}

with Al-Nobaria silage samples. Depending on invitro and in-situ results for silage type results, in vitro and in-situ for silage type from Al-Salhia area had a best characteristics of good silage and was chosen forever conducting lactation trial.

Key words: corn silage, evaluation, in-vitro, in-situ

\section{INTRODUCTION}

Sustainability of dairy sector is achieved by sustainable profitable milk production, and sustainable quality environment which emphasizes the need for integral solutions to sustainability problems in the livestock production sector. Perhaps, the biggest problem facing dairy profitability is the feeding cost. So, we will focus on this problem constrain the dairy sector sustainability. Feed is the largest single cost item for livestock and poultry production, accounting for $60 \%-70 \%$ of the total cost in most years (2008). Although energy, labor, and other inputs have increased, feed costs have increased anywhere from 40\%-60\% (depending on the species) in the last two years. To date, rising costs have largely been absorbed by livestock producers, often with significant financial loss. However, higher costs of production will ultimately have to be reflected in higher prices for meat and milk at retail counters in the United States and elsewhere. When analyzing the impact of escalating feed costs on animal farm, it was found that a variety of factors have contributed to higher feed grain prices as revolution of biofuel production. John et al (2008) and Jim (2015) showed that corn prices began increasing dramatically because of explosion in the production of corn ethanol plants started at 2006, also rising consumption of 
meat and milk in developing countries escalating feed costs, milk consumption has rapidly increased, and the annual per capita consumption of milk in developing countries is projected to increase from $52 \mathrm{~kg}$ in 2005 through 2007 to $66 \mathrm{~kg}$ in 2030 and $76 \mathrm{~kg}$ in 2050 (Alexandratos and Bruinsma, 2012), and the environmental condition as drought also escalating feed costs, droughtinduced crop yield loss is considered among the greatest losses in agriculture (Lobell et al 2011).

Salfer (2015) reported that the dairy profitability has been affected by high feed prices similar to other livestock species. 2009 was the lowest profitability year in history. Many producers lost in excess of $\$ 100 /$ cow per month for several months. Year to year profit volatility has increased tremendously. Net return averaged \$480/cow from 2000 to 2006 with a low of $\$ 268 / \mathrm{cow}$ in 2002 to $\$ 678 /$ cow in 2005. From 2007 to 2013 net return averaged $\$ 354 /$ cow with a range from $\$-189 /$ cow in 2009 to $\$ 881 /$ cow in 2007 . For Beef Industry, the production costs have risen sharply in the cattle sector, primarily as a result of rising feed costs, John et al (2008).

In case of higher corn prices and subsequent increases in other grain prices strategies need to be implemented to reduce feed costs without disrupting the rumen environment such as feed more corn silage. Forages such as corn silage will become a natural choice as the primary forage in rations when corn grain is partially removed. Corn silage is low in protein and provides fermentable starch, energy, and relative amounts of effective fiber (depending on its particle size). As grain prices have increased since the 2006 harvest, forage utilization has increased by $5-10 \%$ on a DM basis, often with little or no decrease in milk yield (Knapp, 2008).

Allen (2001) reported that when feeding higher corn silage diets will allow dairy producers to feed decreasing corn diets with excellent performance. Delaby et al (2009) noted that when using 65\% corn silage plus $5 \%$ alfalfa hay plus $30 \%$ concentrate in dairy ration he found that dairy cows consumed DMI $20 \mathrm{Kg} / \mathrm{d}$ and produced $33.5 \mathrm{~kg}$ milk/d with $4 \%$ Fat. Shahira et al (2008) fed dairy cows on corn silage with different concentrations $25 \%$, $50 \% 75 \%$ corn silage with $15 \mathrm{~g}$ protected methionine. They found that milk production and fat were improved by $7.5 \%$ for $75 \%$ corn silage and with supplement methionine detected higher milk fat and protein and reproductive performance.

The main objective of this study was to achieve dairy farming sustainability by corn silage supple- mentation as a percent of dry yellow corn to decrease feeding cost. The sub-objective was to evaluate fermentation parameters of different silage samples In-vitro and evaluate the in-Situ degradability of the different silage samples.

\section{MATERIALS AND METHODS}

\section{Silage sampling plan}

Silage samples (approximately $4 \mathrm{~kg}$ ) were collected from four regions; El-Nobria and Ganakles which belong to El Beheirah Governorate, ElSalhia which belongs to Al Esmailia Governorate and El- Monofia governorate. Each sample was divided into two parts, the first part was frozen and other part was dried in a forced air oven at $60^{\circ} \mathrm{C}$ for 24 hours. The dried samples were ground to pass a $1 \mathrm{~mm}$ sieve in a Wiley mill and used for chemical analysis and for In-Vitro and In-Situ trials.

\subsection{Silage evaluation plan}

The present study was carried out at two steps. The first was the In-vitro experiment and it was conducted in Regional Center for Food and Feed Lab., Giza Governorate, Egypt in March, 2017. The second was In-Situ experiment and conducted in King Marriott Research farm belong to Desert Research Center located in Alexandria Governorate, Egypt in April, 2017

\subsection{Quality parameters of silage samples}

The frozen samples were used to determine silage quality parameters. Samples of $50 \mathrm{~g}$ silage were mixed with $450 \mathrm{ml}$ distilled water in food mixer for 5 minutes, then filtered using 4 layers of cheesecloths and withdrawn to a sample bottle and then stored at $-20^{\circ} \mathrm{C}$ in deep freezer until subsequent analysis. The $\mathrm{pH}$ values were measured immediately using $\mathrm{pH}$ Metter (Hannah's pen). The ammonia concentration $\left(\mathrm{NH}_{3} \mathrm{~N}\right)$ was determined according to Conway (1962). Total volatile fatty acids (VFA's) concentration was determined by steam distillation methods as described by Warner (1964).

\subsection{In-vitro}

In-vitro batch culture trial was applied according to procedures of Menke and Steingass (1988), to compare the different silage samples. Rumen fluid was obtained from slaughterhouse 
and it was collected from three steers. The collected rumen fluid was mixed and squeezed through 4 layers cheesecloth into a 1 liter bottle (1L) with an $\mathrm{O}_{2}$-free headspace and immediately transported to laboratory at $39^{\circ} \mathrm{C}$ where it was used as a source of inoculum. About $200 \mathrm{mg}$ dry weights of samples were weighed into calibrated glass syringes of 100 $\mathrm{ml}$. Each sample was tested in 3 replicates accompanied by blank vessels (no substrate). Rumen fluid was mixed with $200 \mathrm{ml}$ buffer solution (Buffer A): Ammoniabicarbonate $\mathrm{NH}_{4}\left(\mathrm{HCO}_{3}\right)$, Sodium bicarbonate $\left(\mathrm{NaHCO}_{3}\right)+$ Buffer $\mathrm{B}$ : sodiumdihydrogen phosphate $\left(\mathrm{Na}_{2} \mathrm{HPO}_{4}\right)$, anhydrous potassium dihydrogen phosphate $\mathrm{KH}_{2} \mathrm{PO}_{4}$, anhydrous magnesium sulfate heptahydrate extra pure $\left(\mathrm{MgSO}_{4} .7 \mathrm{H}_{2} \mathrm{O}\right)+0.1 \mathrm{ml}$ micro-mineral solution, 200 $\mathrm{ml}$ macro-mineral solution, and $1 \mathrm{ml}$ Resazurin solution per $500 \mathrm{ml}$ of distilled water. Carbon dioxide $\left(\mathrm{CO}_{2}\right)$ gas was flushed through the solution until the color turned. The syringes were pre warmed at $39^{\circ} \mathrm{C}$ before the injection of $30 \mathrm{ml}$ of rumen fluid-buffer mixture into each syringe followed by incubation in a water bath at $39^{\circ} \mathrm{C}$ for $24 \mathrm{~h}$.

\subsection{Total gas production determination}

- SCFA (mmol/200 mg DM) $=-0.00425+$ 0.0222 * GP (Eq. 1).

- $\quad 1 \mathrm{MJME}=0.4185 \mathrm{Mcal} \mathrm{ME}$ (Eq. 2).

- Where: The GP is net GP in $\mathrm{mL}$ from 200 $\mathrm{mg}$ of dry sample after $24 \mathrm{~h}$ of incubation, $2.2 \mathrm{mg} / \mathrm{mL}$ is a stoichiometric factor that expresses $\mathrm{mg}$ of $\mathrm{C}, \mathrm{H}$, and $\mathrm{O}$ required for the SCFA gas associated with production of $1 \mathrm{~mL}$ of gas.

\subsection{In-Situ trial}

DM disappearance for silage samples in the rumen was done according to Mehrez and Orskov (1977).

\subsection{Animals, feeding and bags}

Three mature Barki rams (60 kg and about one yearold) were used. Each animal was fitted with a rumen cannula (40 $\mathrm{mm}$ diameter) about two months before the experiment commenced. The animals were kept in individual pens and were fed ad libitum on alfalfa hay plus one $\mathrm{Kg}$ concentrate feed mixture (12\% protein). The bags used in this experiment were made from of Dacron material, the number of holes per $\mathrm{cm}^{2}$ was about 1940, the bags were made to assize of $8^{\star} 5 \mathrm{~cm}$.

\subsubsection{In-Situ Procedures:}

The in-situ DM degradation analysis was carried out according to the procedure described by Mehrez and Orskov (1977). The silage samples were dried and grinded in Willy mille (3-mm sieve). Five $g$ of silage samples were weighed into nylon bags and incubated in three rumen fistulated sheep for $0,2,4,8,12$ and $24 \mathrm{~h}$ (three replicates for each time). On removal the nylon bags were thoroughly washed with cold running water until no further coloured liquid could be extruded, and dried at $60^{\circ} \mathrm{C}$ for $48 \mathrm{~h}$. Dry matter (DM) losses for each incubation time were determined.

\subsection{Statistical analysis}

In-vitro studies results were analyzed according to one way statistical analysis system (SAS) User's Guide (1998). Separation among means was carried out by using Duncan multiple tests, (1955). According to the following model:

$$
Y_{i j}=\mu+T_{i}+e_{i j}
$$

Where: $y_{\mathrm{ij}}$ : represents observation, $\mu$ : the overall mean, $\mathrm{T}_{\mathrm{i}}$ : effect of treatment (experimental group) and $e_{i j}$ : experimental error.

While, in-situ results for rumen degradation kinetics for DM degradation data were calculated following the model proposed by Ørskov and McDonald (1979) and analyzed by using software of SAS (1998) non-linear regression procedure (PROC NLIN)

$$
Y=a+b\left(1-e^{-c t}\right)
$$

Where: $Y=D M$ degradation in rumen at time $(t)$,

$$
\mathrm{a}=\text { Water soluble (or rapidly degraded) }
$$
fraction (at T0),

$\mathrm{b}=$ the slowly degradable (or potentially degradable) fraction

$\mathrm{c}=$ Rate of degradation of (b), and $\mathrm{t}=$ Incubation time i.e. 2, 4, 6, 12 and $24 \mathrm{hrs}$.

Following determination of this parameter, the effective degradability of DM was calculated using equation described by Ørskov and McDonald (1979):

$$
E D=a+[(b \times c) /(c+k)]
$$


The un-degradable fraction $(U)$ was calculated as: $U=100-(a+b)$. Effective degradability (ED) of DM, assuming constant rumen passage rates $(k)$ of $0.02 \mathrm{~h}^{-1}$ for each ingredient.

\section{RESULTS AND DISCUSSION}

\section{Chemical composition of the tested silage samples}

The data of proximate chemical analysis of different silage samples and calculated nutritive values are presented in Table (1). The data showed that the values of DM, OM, ash, CP, NDF, lignin and $G E$ are within the normal range for all silage samples (El-Salhya, El-Nobaria, El-Monofya and Ganakles) as reported in Table (1). However, the values of crude fiber (CF) for El-Nobaria and ElMonofya silage samples were out of the range reported by Ali et al (2016) (13.8-22.8\%), Also the values of ADF contents for El-Nobaria, El-Monofya and Ganakles silage samples were higher than the range reported by Nazier et al (2014) and the values of calculated gross energy (GE) values for ElNobaria, El-Monofya and Ganakles silage samples were lower than these values reported by Hassanat et al (2013). Based on the chemical composition data, it is interest to note that El-Salhya silage sample recorded the best values in most instance compared to the other samples and according the stated references in Table (1). The wide range of chemical composition results reported in Table (1) may be due to that the authors used a lot of number of samples, different strains, different maturity and different moisture and ash content. In this connection Seglar (2003) reported that there were a wide range of the chemical composition or silage quality due to some factors such as moisture $\%$, maturity stage, crude protein\%, ash\%, $\mathrm{PH}$, ammonia nitrogen and microbial counts.

Table 1. Chemical composition of the tested silage samples on DM basis.

\begin{tabular}{|c|c|c|c|c|c|c|}
\hline Items & $\begin{array}{c}\text { El- } \\
\text { Salhya }\end{array}$ & El-Nobrya & $\begin{array}{c}\text { El- } \\
\text { Monofya }\end{array}$ & Ganakles & $\begin{array}{c}\text { Normal } \\
\text { Range }\end{array}$ & References \\
\hline DM\%* & 35.4 & 30.09 & 28.2 & 29.7 & $19.2-48.1$ & Ferreia and Mertens (2005) \\
OM \%* & 96.27 & 96.49 & 95.9 & 96.06 & $90.4-96.9$ & Ferreia and Mertens (2005) \\
Ash \%* & 3.73 & 3.51 & 4.1 & 3.94 & $3.1-9.6$ & Ferreia and Mertens (2005) \\
CP \%* & 7.8 & 8.3 & 7.5 & 6.1 & $5.7-12.5$ & Ferreia and Mertens (2005) \\
CF\%* & 22.57 & 28.07 & 27.48 & 22.86 & $13.8-22.8$ & Ali et al (2016) \\
NDF \%* & 52.8 & 65.4 & 56.9 & 55.6 & $20.7-65.9$ & Nazir et al.(2014) \\
ADF \%* & 31.8 & 41.8 & 38.5 & 37.4 & $15.2-33.4$ & Nazir et al.2014 \\
Hemi Cellulose \%* & 21.03 & 23.48 & 18.4 & 18.2 & $15-23$ & Vishler and Gabriella 2016 \\
Lignin \%* & 6.22 & 6.32 & 5.04 & 5.5 & $4.6-9.2$ & Swift 2004 \\
GE cal/g* & 4243 & 4115 & 4046 & 3907 & 4200 & Hassanat et al 2013 \\
TDN** & 64.39 & 61.44 & 64.85 & 64.48 & $46.4-70$ & Isabella et al 2007 \\
\hline *determined according to A.O.A.C. (1995) \\
**calculated according to NRC (2001)
\end{tabular}

\subsection{Characteristics of tested silage samples}

The data of silage quality for different samples are presented in Table (2). According to Oliveira et al (2017), good corn silage has PH 3.6-4.1, so all our samples were within the $\mathrm{PH}$ normal range except Ganakles silage sample (4.28).Concerning ammonia N Selgar (2003) reported that good silage should have ammonia- $\mathrm{N} \mathrm{NH}_{3} \mathrm{~N}$ (\% of Total Nitrogen) $<10 \%$ so all samples are normal range. Wilkinson (1990) cited that well-preserved silages should have an ammonia-N concentration $<100$ $\mathrm{mg} / \mathrm{ml}$ So all different samples were in normal range. Total TVFA's $\mathrm{ml} \mathrm{mol} / \mathrm{dl}$ for El-Salhya and Ganakles samples were within normal range ac- cording to Akila et al (2009), who reported that the normal range concentration of TVFA's for whole corn silage was $2.25-2.55 \mathrm{mlmol} / 100 \mathrm{ml}$.

Table 2. Silage quality parameters of diffrent samples

\begin{tabular}{|c|c|c|c|c|}
\hline & $\begin{array}{c}\text { El- } \\
\text { Salhya }\end{array}$ & $\begin{array}{c}\text { El- } \\
\text { Nobrya }\end{array}$ & $\begin{array}{c}\text { El- } \\
\text { Monofya }\end{array}$ & Ganakles \\
\hline $\mathrm{PH}$ & 3.92 & 3.85 & 3.93 & 4.28 \\
$\mathrm{NH} 3-\mathrm{N} \%$ & 0.59 & 0.52 & 0.71 & 0.76 \\
Ammonia mg/100 ml & 13.28 & 15.93 & 10.62 & 7.97 \\
TVFA mmol/100 ml & 2.55 & 1.28 & 1.66 & 2.3 \\
\hline
\end{tabular}


3 The In-vitro evaluation of tested silage samples

\subsection{Gas production}

The data presented in Table (3) and Figure (1) showed that Ganakles samples recorded lowest significant $(P=0.001)$ gas production at different times compared to the other samples (El-Salhya, El-Nobarya and El-Monofia). While no significant differences were recorded among El-Salhya, ElNobarya and El-Monofia samples at different times. This may be due to Ganakles silage sample recorded lower fermentation characteristics and GE value compared to the other silage samples (Table 3 and Figure 1). In this connection Bovera et al (2006) found that the total accumulated gas after 48 hour for different silage samples were ranged from 140-180 ml/g DM.

Table 3. In-vitro Gas production (ml/1 $\mathrm{g} \mathrm{DM})$ at different times of incubation for different silage samples

\begin{tabular}{|c|c|c|c|c|c|}
\hline Time & El-Salhia & El-Nobria & El-Monofia & Ganakles & SE \\
\hline at 2 h. & $22.96^{\mathrm{e}}$ & $20.97^{\mathrm{e}}$ & $25.39^{\mathrm{e}}$ & $14.38^{\mathrm{e}}$ & 3.34 \\
at 4 h. & $40.42^{\mathrm{d}}$ & $36.45^{\mathrm{d}}$ & $40.81^{\mathrm{d}}$ & $23.23^{\mathrm{d}}$ & 3.34 \\
at 8 h. & $53.55^{\mathrm{c}}$ & $65.19^{\mathrm{c}}$ & $44.00^{\mathrm{c}}$ & $28.00^{\mathrm{c}}$ & 3.34 \\
at 16 h. & $65.38^{\mathrm{c}}$ & $71.82^{\mathrm{C}}$ & $47.43^{\mathrm{c}}$ & $32.06^{\mathrm{C}}$ & 3.34 \\
at 24 h. & $149.58^{\mathrm{b}}$ & $146.97^{\mathrm{b}}$ & $131.27^{\mathrm{b}}$ & $118.31^{\mathrm{b}}$ & 3.34 \\
at 48 h. & $165.99^{\mathrm{a}}$ & $150.31^{\mathrm{a}}$ & $145.60^{\mathrm{a}}$ & $132.66^{\mathrm{a}}$ & 3.34 \\
P Value & 0.0003 & 0.0001 & 0.0001 & 0.0001 & 0.0001 \\
\hline
\end{tabular}

Regarding to the effect of the incubation time, the data of Table (3) and Figure (1) showed that ther was gradual increase $(P=0.0001)$ for gas production with time for all samples. These data agreed with Calabro et al. (2007), who founed that In-vitro gas production was increased gradualy with incresing time of icubation of in-vitro fermintation of corn silge. This finding can be assesed by Blümmel and Orskov (1993), who observed a positive correlation between DM disappearance and gas production.

\subsection{In-vitro calculated parameters}

The data of Table (4) showed calculated OMD, ME and SCFA for the different silage samples based on in-vitro gas production test. The data showed that El-Salhya and El-Nobria samples recorded significant $(P=0.001)$ higher values of $M E$, OMD and SCFA values compared to El-Monofia and Ganakles results. Besides, El-Monofia recorded significant higher values of ME, OMD and SCFA than these of Ganakles samples. This data agreed with Ali et al (2016), who reported that Invitro organic matter degradability of corn silage ranged between (70\%-80\%) after $32-72$ hour of incubation. Also our data agreed with Elghandour et al (2015), they reported that calculated ME of corn silage were between 1.5-1.7 Mcal $/ \mathrm{kg}$ DM when tested whole corn silage without concentrates by in-vitro method using gas production technique after 72 hour incubation time. But less than the values of the same author when they reported a calculated SCFA of corn as $(3.23 \mathrm{mmol} / \mathrm{g}$ DM.)

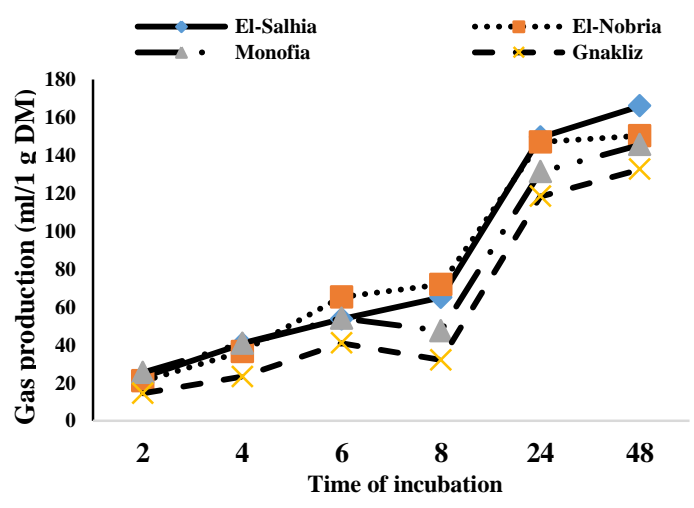

Fig. 1. Gas production accumulation at different times of in-vitro fermentation for the tested silage samples ( $\mathrm{ml} / \mathrm{g} \mathrm{DM})$

Table 4. Calculated in-vitro ME, OMD and SCFA of the different silage samples

\begin{tabular}{|c|c|c|c|}
\hline Areas & $\begin{array}{c}\text { ME (Mcal/Kg } \\
\text { DM) }\end{array}$ & $\begin{array}{c}\text { OMD } \\
(\%)\end{array}$ & $\begin{array}{c}\text { SCFA (mmol /g } \\
\text { DM })\end{array}$ \\
\hline El-Salhia & $1.60^{\mathrm{a}}$ & $76.39^{\mathrm{a}}$ & $0.659^{\mathrm{a}}$ \\
El-Nobria & $1.59^{\mathrm{a}}$ & $78.39^{\mathrm{a}}$ & $0.648^{\mathrm{a}}$ \\
Monofia & $1.49^{\mathrm{b}}$ & $72.04^{\mathrm{b}}$ & $0.578^{\mathrm{b}}$ \\
Ganakles & $1.38^{\mathrm{c}}$ & $63.43^{\mathrm{c}}$ & $0.521^{\mathrm{c}}$ \\
SE & 0.689 & 0.689 & 0.02 \\
PV & 0.0007 & 0.0001 & 0.0015 \\
\hline
\end{tabular}

\subsection{In-situ Evaluation of tested silage samples}

\subsubsection{Extent of DM degradability}

The date of extant degradability of dry matter for the different silage samples are presented in Table (5). It could noticed that El-Salhia samples recorded the highest in-Situ degradability at different times 2, 4,8,16, and $24 \mathrm{hrs}$ in most instance as 
well as the mean. While Ganaklize sample recorded the lowest in-Situ dry matter degradability and the differences were significant at $(P=0.001)$. As expected, the data indicated that in-Situ dry matter degradability significantly $(P=0.001)$ increased with time of incubation. This data agreed with Ali et al (2016) who reported that the DMD of corn silage were increased with increasing of incubation time. Nevertheless, the present results of DM degradability for different silage samples disagree with those reported by result of Jurjanz and Monteiles (2005) who found that the In-Situ degradability of whole corn silage was $75 \%$ after $24 \mathrm{hrs}$ of incubation. Also Ali et al (2016) reported that the average of in-Situ DM degradability was $52.5 \%$ after 24 hrs. of incubation. Concerning the effect of time incubation, the data of Table (5) and Figure (2) revealed gradual increase with time for In-Situ DMD with time for all samples.

Table 5. Extent degradability (\%) of In Situ DMD of silage samples at different time of incubation

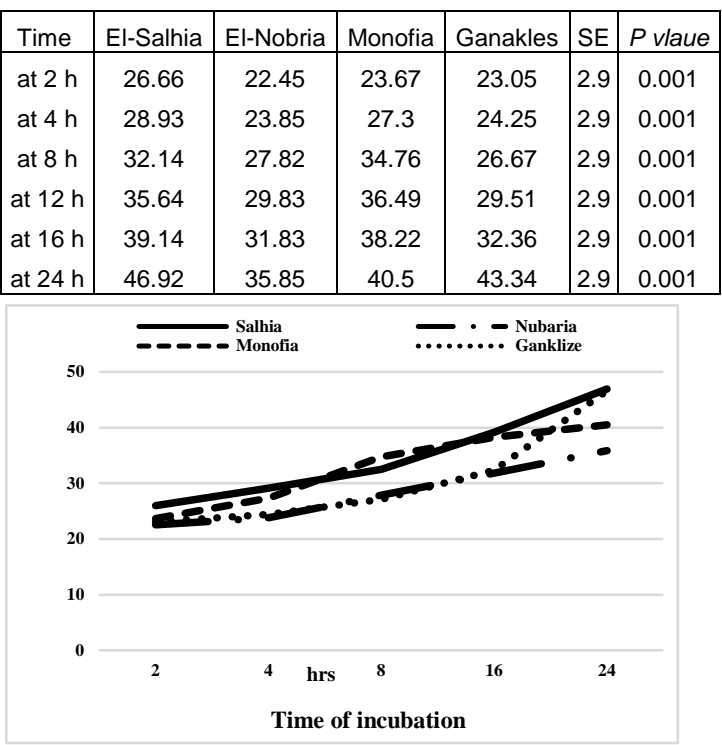

Fig. 2. Extent degradability of In-Situ dry matter of silage samples at different times of incubation.

\subsubsection{Degradation rate of DM at different incu- bation times}

As shown in Table (6), the rate of degradation for different silage samples started high (from 0 to 2 hrs. for all silage samples then gradually decreased in the following intervals. The highest degradation rate at 0 to $2 \mathrm{hrs}$ was recorded for $\mathrm{El}$ -
Salhya samples followed by El-Monofiea samples while the lowest degradation rate was recorded for El-Nubaria Silage samples. These data agreed with these of Jurjanz and Monteil (2005), who reported that the rate of degradability per hour of ensiled hole corn silage or fresh whole corn plant were 0.99 hrs by using in-Situ measurements carried out using four ruminal cannulated lactating multiparous Holstein cows. The animals were fed adlibitum a total mixed ration composed of corn silage, and sample bags were incubated for 1, 3, 6, 12, 24, and $48 \mathrm{hrs}$.

Table 6. Degradation rate (\%) of In-Situ DMD at different interval times of silage samples.

\begin{tabular}{|c|c|c|c|c|}
\hline Time interval & El-Salhia & El-Nubaria & El-Monofia & Ganklize \\
\hline From 0h.-2h. & 13.002 & 11.2741 & 11.8356 & 11.5254 \\
From 2h.-4h. & 1.57152 & 0.65226 & 1.81433 & 0.68124 \\
From 4h.-8h. & 0.83213 & 0.99296 & 1.86597 & 0.68124 \\
From 8h.-12h. & 0.83269 & 0.50131 & 0.4333 & 0.65211 \\
From 12h.-16h. & 0.83269 & 0.50131 & 0.4333 & 0.65211 \\
From 16h.-24h. & 0.97324 & 0.50131 & 0.28366 & 1.78949 \\
Extent & 34.63 & 28.38 & 32.89 & 29.93 \\
\hline \multicolumn{4}{|r}{}
\end{tabular}

\subsubsection{In-Situ parameters of different silage} samples

Table (7) showed the data of in-Situ ruminal kinetic parameters of different silage samples. the obtained results showed that there were numerical differences among samples in soluble fraction, rapidly degradable portion (a). El-Salhia sample was the highest one but El-Nobria sample was the lowest one, while highest slowly degradable fraction, potential degradability (b), were recorded for El-Nobria sample and the lowest value was recorded for El-Monofia sample. Moreover, it is worthy interest to note that the lowest un-degradable fraction (U) was recorded for El-Salhya sample while the highest un-degradable fraction (U) were highest in El-Monofia sample. Effective degradable dry matter (Eddm) was the same for all samples at $2 \%$ passage rate (Table 7 ). The present data disagreed with Ali et al (2016) who reported that average values for rumen un-degradable $(U)$ fraction, degradation rate (c) effective rumen degradability (Eddm) at $2 \%$ passage rate a of maize silage samples were (16,42 and 53\%, respectively). However the data agreed with them when they reported that potentially rumen degradable $(a+b)$ fraction was $55 \%$.Data also disagreed with DiMarco et al 
(2005) who reported that soluble fraction (a) was in average $32 \%$, the degradable fraction (b) $43 \%$ and the fractional degradation rate (c) $4.45 \% / \mathrm{h}$.

Table 7. Ruminal kinetic parameters of different silage samples.

\begin{tabular}{|c|c|c|c|c|c|c|}
\hline Sample & $\mathrm{a}^{1}$ & $\mathrm{~b}^{2}$ & $\mathrm{U}^{3}$ & $\mathrm{a}+\mathrm{b}$ & $\mathrm{c}^{4}$ & $\begin{array}{c}\mathrm{Eddm}^{5} \\
(\mathrm{~K}=0.02 \mathrm{~h}-1)\end{array}$ \\
\hline El-Salhia & 23.59 & 42.71 & 33.70 & 66.30 & $0.03 \mathrm{~b}$ & 50.14 \\
El-Nobria & 13.81 & 50.85 & 35.33 & 64.67 & $0.05 \mathrm{~b}$ & 50.66 \\
El-Monofia & 16.21 & 39.23 & 44.56 & 55.44 & $0.13 \mathrm{a}$ & 50.16 \\
\hline
\end{tabular}

'a: Soluble fraction at zero time, ${ }^{2} \mathrm{~b}$ : Slow degradable fraction,

${ }^{4} \mathrm{C}$ : Passage rate at $2 \% / \mathrm{hr} \cdot{ }^{3} \mathrm{U}$ : un-degradable fraction.

${ }^{5}$ Eddm: Effective degradable dry mater

\section{CONCLUSION}

According to the previous result the best silage sample was El-Salhia because its chemical composition values were the best one (DM, OM, CF, NDF, CP and GE), good quality characteristics sample ( $\mathrm{PH}, \mathrm{NH} 3-\mathrm{N}$ and Ammonia), In-Vitro evaluation (gas production, ME and SCFA), in-Situ evaluation (Extant DMD and degradation rate of DM).

\section{REFERENCES}

Akila, S.H., EL-Shinnawy, M.M., Emara, M.F., Thanaa F. Mohammadi and EL-Shinnawy, A.M., 2009. Use of different silages as new feed resources for ruminants. Archiva Zootechnica 12(2), 79-88.

Alexandratos, N. and Bruinsma J., 2012. World agriculture towards 2030/2050. ESA Working paper No. 12-03, pp. 1-61, FAO, Rome, Italy.

Ali, M., Cone, J.W., van Duinkerken, G., Klop, A., Blok, M.C., Bruinenberg, M., Khaf, N.A. and Hendriks, W.H., 2016. Variation between individual cows in in situ rumen degradation characteristics of maize and grass silages. NJAS-Wageningen J. of Life Sci. 78, 167173.

Allen, D., 2001. Dry matter and neutral detergent fiber intake of dairy cattle. Ph.D., Dept., Fac.. University of Minnesota, USA, pp. 30-45.

A.O.A.C., 1995. Association of Official Analytical Chemists. Official Methods of Analysis. $16^{\text {th }}$ Ed. Washington, D.C., USA.
Blummel, M. and Orskov, E.R. 1993. Comparison of in vitro gas production and nylon bag degradability of roughages in predicting of food intake in cattle. Animal Feed Sci. Technol. 40, 109-119.

Bovera, F., Mora, F., Meo, C.D. and Nizaa, A., 2006. Use of the in vitro gas production technique to study feed digestibility in domesticated ostriches (Struthiocamelus var. domesticus). Ann. Anim. Sci. 16(3), 769-777.

Calabrò, S., D’Urso, S., Banoin, M., Piccolo, V. and Infascelli, F., 2007. Nutritional characteristics of forages from Niger. Ital. J. Animal Sci. 6(1), 272-274.

Conway, E.F., 1962. Microdiffusion analysis and volumetric error. Rev. Ed. Lookwook, pp. 357365. London. UK.

Delaby, L., Faverdin, P., Michel, G., Disenhaus, C. and Peyraud, J.L., 2009. Effect of different feeding strategies on lactation performance of Holstein and Normande dairy cows. Animal 3 (6), 891-905.

Di Marco, O.N., Aello, M.S. and Arias S. 2005. Digestibility and ruminal digestion kinetics of corn silage Arq. Bras. Med. Vet. Zootec. 57, (2), 223-228.

Duncan, D.B., 1955. Multiple range and multiple $F$ test. Biometrics. 11, 1-42.

Elghandour, M.M., Ahmed, E.Kh., Adrian, Z.B., Dora, P.M. and Abdelfattah, Z.M.S. 2015. Invitro gas production of five rations of different maize silage and concentrate rations influenced by increasing levels of chemically characterized extracted of salixbabylonica. Turk. J. Vet. Anim. Sci. 39, 186-194.

Hassanat, F., Gervais, R., Julien, C., Massé, D., Lettat, A., Chouinard, P.Y., Petit, H.V. and Benchaar, C., 2013. Replacing alfalfa silage with corn silage in dairy cow diets: effect on enteric methane production, ruminal fermentation, digestion, $\mathrm{N}$ balance and milk production. J. Dairy Sci. 96, 4553-4576.

Jim, S., 2015. Economics of dairy, beef and feed and how it relates to Energy, $53^{\text {rd }}$ Annual Rural Energy Conference. February, 19-20, pp. 1-5.

John, D., Mintert, J., Anderson, J.D. and Anderson, D.P. 2008. Feed grains and livestock: Impacts on meat Supplies and prices. Choices, $2^{\text {nd }}$ Quarter 23(2), 11-15.

Jurjanz, S. and Monteils, V., 2005. Ruminal degradability of corn forages depending on the processing method employed. Anim. Res., 3, 15-23. 
Knapp, J.R., 2008. Strategies for diet formulation with high corn prices. Tri-State Nutrition Conference, April 24 pp. 87-95.

Lobell, D.B., Schlenker, W. and Costa-Roberts, J., 2011. Climate trends and global crop production since 1980. Science. 333(6042), 616620.

Mehrez, A.Z. and Ørskov, E.R., 1977. A study of the artificial fibre bag technique for determining the digestibility of feeds in the rumen. J. of Agric. Sci. Camb. 88, 645-650.

Menke, H.H. and Steingass, H., 1988. Estimation of the energetic feed value obtained from chemical analysis and in vitro gas production using rumen fluid. Anim. Res. and Devel. 28, 7-55.

Nazier, A.Kh., Peiqiang, Y.U., Mubarak, A., John, W.C. Wouter and Hendriks, H. 2014. Nutritive value of maize silage in relation to dairy cow performance and milk quality. $\mathbf{J}$.Sci Food Agric.95, 238-252.

Oliveira, C.A.F., Fernandes, A.M., Neto. O.C.C., Fonseca, L.F.L., Silva, E.O.T. and Balian, S.C., 2017. Composition and sensory evaluation of whole yogurt produced from milk with different somatic cell counts. Aust J. Dairy. Technol., 57, 192-196.
Ørskov, E.R. and McDonald, I., 1979. The estimation of protein degradability in the rumen from incubation measurements weighted according to rate of passage. J. of Agric. Sci. Camb. 92, 499-503.

Salfer, J., 2015. Economics of dairy, beef and feed and how it relates to energy. $\mathbf{5 3}^{\text {rd }}$ Annual Rural Energy Conference, pp. 1-5.

SAS., 1998. SAS User's Guide, ed. SAS Institute Inc. Cary, NC, USA.

Seglar, B., 2003. Fermentation analysis and silage quality testing. Proceedings of the Minnesota Dairy Health Conference, College of Veterinary Medicine, University of Minnesota, May, USA, pp. 119-133.

Shahira M.M., El-Ashry, M.A., Ibrahim, S.A., ElMekass, A.A.M. and Khorshed, M.M.A., 2008. Effect of feeding different concentrate: Corn silage rations with or without protected methionine supplement on productive and reproductive performance of lactating cows. EAAP Annual Meetings, pp. 1-6.

Warner, A.C.L., 1964. Production of volatile fatty acids in the rumen: Methods of measurement. In Nutrition Abstracts and Reviews. 34, 339352.

Wilkinson, M., 1990. Silage, UK. $6^{\text {th }}$ Ed, Chalcombe Publications, Marlow, UK, pp. 13-27. 
المؤتمر الرابع عثر لبحوث التنمية الزراعية،

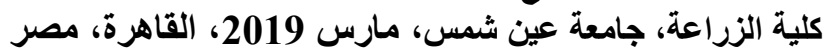

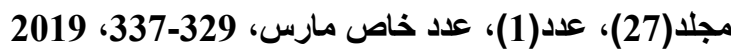

Website: http://strategy-plan.asu.edu.eg/AUJASCl/

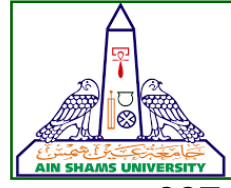

337

\section{دراسده تقيم عينات سيلاج أذره من مناطق مختثفه فى جمهوريه مصر العربيه}

ايهاب نصر داود 1- حسين سعد سليمان2 ${ }^{2}$ - حمدي محمد السيد2 - نصر السيد البرديني2-

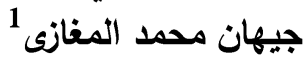

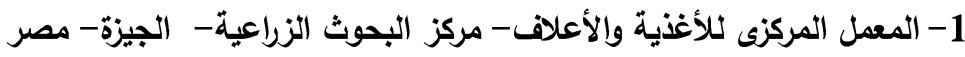

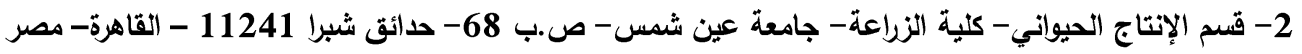

"Corresponding author: Manaressam92@gmail.com

Received 28 August, 2018, Accepted 2 October, 2018

كرش الاغنام باستخدام الفاستيولا الى ان هضان الفم الماده

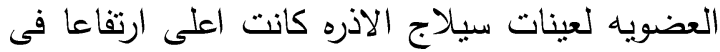

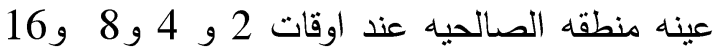

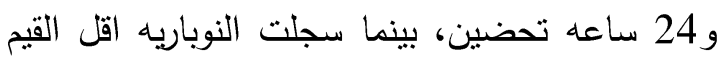
هضما للماده العضويه.

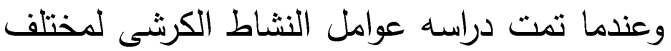

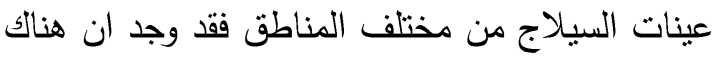

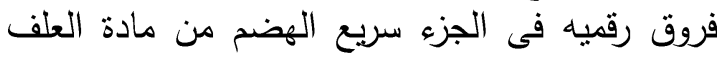

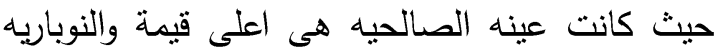

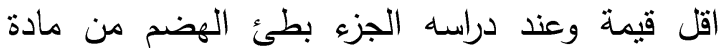

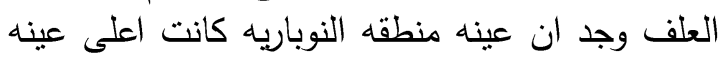

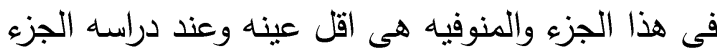
غير المهضوم من ماده العلف فقد وجد ان القل فئل عينه

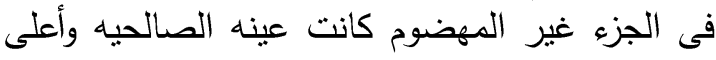

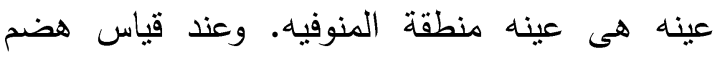

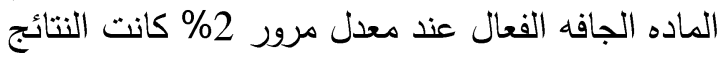
متساوية لكل العينات من مختلف المناطق.

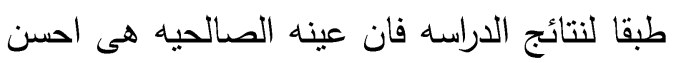

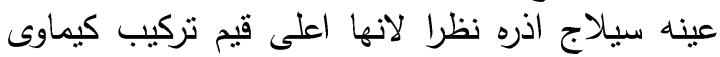

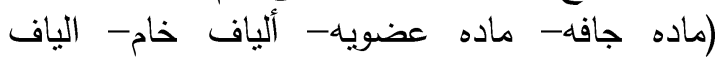

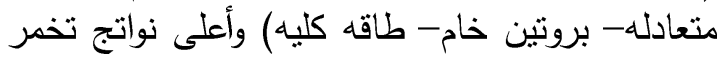

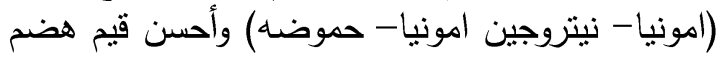

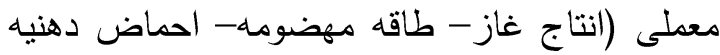

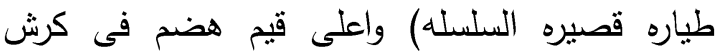
الاغنام باستخدام fistula (معدل هضم - هضم هضم

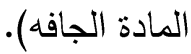

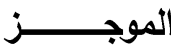

أجريت هذة الدراسه بهدف تقييم عينات سيلاج

الاذره كامله الحبوب من عدة لأل محافظات بجمهوريه مصر العربيه لتحديد الى العينات اعلى فلى التى القيم

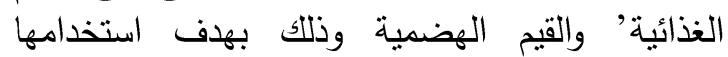
لاحلال نسبه 10\% من حبوب الاذره الجافه اضافه

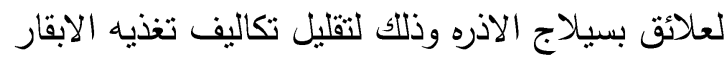

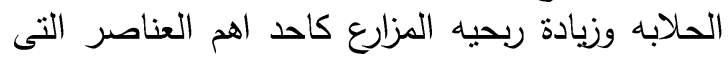
تساهم فى تحقيق الاستدامه فى قطاع مزارع الالبان.

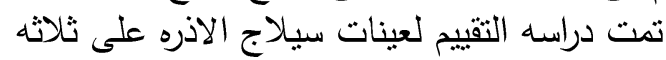

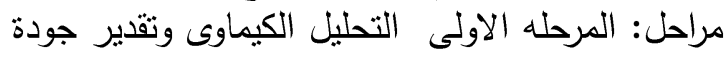

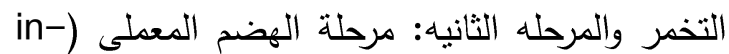

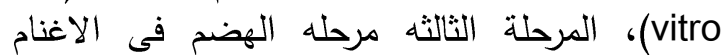

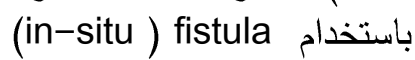
اثشارت النتائج المتحصل عليها من مرحله الهضم

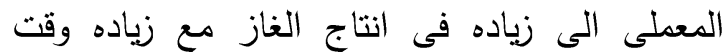

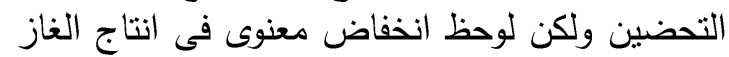

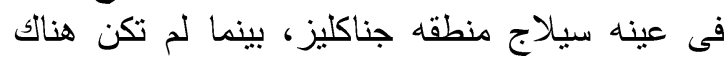

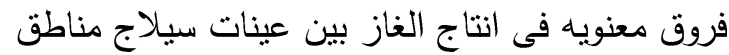

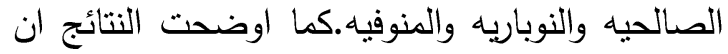

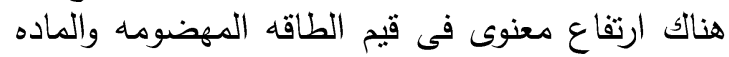

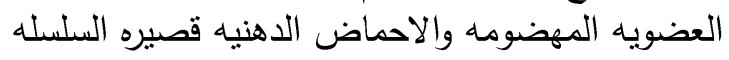
لعينة منطقة الصالحيه وانخفاض معنوى في الطيه الطاقه

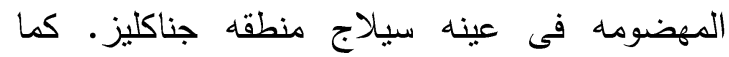

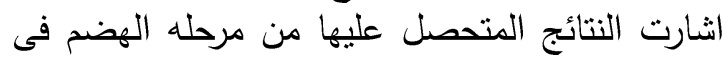

